\title{
MODALITIES USED BY INDONESIAN AND AMERICAN IN POLITICAL DEBATE DISCOURSE (A COMPARATIVE STUDIES)
}

\author{
Rabiatul Adawiah \\ raratwentyone3@gmail.com \\ Universitas Islam Negeri (UIN) Alauddin Makassar
}

\begin{abstract}
Abstrak
Tujuan penelitian ini adalah untuk mengkaji penggunaan modalitas oleh pembicara dalam debat politik di dua negara: Indonesia dan Amerika Serikat. Penelitian ini merupakan studi perbandingan dengan menggunakan penyajian deskriptif-kualitatif dalam analisis dan tampilan data. Sumber kedua data yakni youtube.com, yang diambil pada April 2014. Hasil penelitian menunjukkan pembicara dalam debat politik baik di Amerika dan Indonesia menggunakan ketiga nilai modalitas: kuat, menengah dan lemah. Pemilihan modalitas tersebut tidak hanya disesuaikan berdasar struktur yang benar, melainkan juga berdasar pada sudut pandang fungsi Bahasa yang diingin dicapai. Politikus menggunakan modalitas kuat untuk menunjukkan komitmen yang kuat terhadap opini dan pendapat yang disampaikan. Sedangkan modalitas menengah dan lemah banyak digunakan oleh presenter meskipun ia ingin menunjukkan komitmen kuat terhadap hal yang dibicarakan. Terakhir, politikus Amerika cenderung lebih eksplisit menujukkan diri sebagai subjek penilai daripada politikus Indonesia dalam debat politik.
\end{abstract}

Kata Kunci: fungsional grammar, modalitas, wacana debat politik.

\begin{abstract}
This study is aimed at investigating modalities used by the speakers of political debate in two countries; Indonesia and USA. This study is a comparative study which uses descriptive qualitative in analysing and displaying data. Both data were taken from youtube.com on April 2014. Firstly, the result of this study shows that the speakers of political debate in Indonesia and America used three values of modality; high, median and low value of modality. A way of choosing modalities does not only with a correct grammar; but also from the functional point of view. Politicians tended to use high value of modality to show their high commitment toward opinion or argument, and presenter tended to use median and low values of modality in offering the other speakers rather than the high
\end{abstract}


value of modality; although the presenter actually wanted to state a requirement that should be followed. Lastly, the English speakers are more explicit to put their selves as the subject of assessment rather than the Indonesian speakers of political debate.

Keywords: functional grammar, modality, political debate discourse

\section{INTRODUCTION}

Political debate is one of the political activities to reach some specific purposes. Mostly, it is held before presidential election to confront all candidates as the speakers. They are given many topics related to the states' problem; and then they are asked to find solution. From the candidates' answer, the viewers can see which candidate has a better solution, so it can be a reference to choose one candidate in presidential election later.

To reach those specific purposes, language plays important role in political debate. It can be seen explicitly through how they convince other speakers and audience that they are better than others, and also how they ruin each other using their argument presented by using language. They offer an opinion, or even they did rebuttal each other in order to reach their political purposes. This notion deals with a concept of power that was proposed by Money et al (2011). They believe that power in political debate does not only come from the institutional status, but also from the language; later it was called by symbolic power.

This notion also deals with the concept from Halliday related to interpersonal function of language. Halliday (1985:53) explained 'there is exchanging roles in the nature of dialogue: statements, questions, offers and commands'. When a speaker states, asks, offers, commands or convinces others, that speaker actually builds a role so that proposition or proposal delivered well to the hearer. And then, when a speaker tries to influence other through his utterance; it can be success actually because of playing a role. It can be seen by paying attention toward the using of modality as Halliday (1985) believed that 'modality reflects a role relationship between the speaker and hearer'. So, in order to explain the structure of language, it is needed to consider its use because there is the speaker's role in constructing language.

Following the previous ideas, one linguistic feature that indicates the level of speakers' commitment toward the proposition of their utterances is modality. It helps the speaker to express their attitude in order to persuade others. It could be such as inclination, allowing, permission, keen, obligation or willing. Modality also can represent possibility, probability and certainty which relates to the truth or possibility in representing a reality. It seems that the study of this linguistic feature is interesting to be conducted, moreover in speech event such as political debate. It can be seen how the choice of modality helps the speaker to persuade the audience or other speakers, including showing their commitment and attitude toward the topic.

In conclusion, the researcher thinks that this notion is interesting to be examined through a study of political discourse. The researcher feels need to do this 
research in order to find out how modality constructed through language by the speaker of political debate. Moreover, the researcher tries to make a comparative a comparative study between political debate in Indonesian and America; so the functional account of modality can be seen universally. In USA, there is always presidential debate before presidential election; the last debate confronted Obama and Romney as the candidates. Meanwhile, in Indonesia there are some programs of political debate are broadcasted regularly such as 'Beda Mega Beda SBY' as an episode of Indonesia Bersuara, a debate program in Metro TV. The speakers came from Demokrat and PDI-Perjuangan party and it was not rare to find them ruin each other. But, the purpose of those political debates is still same namely persuading the audiences and the viewers; make them think that he is better than others to be chose in general election later.

In relation to background in preceding paragraphs, there are some questions that can be formulated. They are as follows;

1. What are the modalities used by the speakers of political debate in America and Indonesia?

2. What are the similarities and the differences between Indonesian and American in using modalities in political debate?

\section{THEORETICAL BACKGROUND}

\section{A. Functional Account of Modality}

Halliday's (1970: 324) approach to defining and categorizing modals is essentially functional in orientation because, as he argues, "in order to explain the structure of language we need to consider its use". And this is precisely what he does in his classification and differentiation between modality and modulation which he further supports by emphasizing grammatical differences between the two groups. According to Halliday (1970: 349), modality is "the speaker's assessment of probability and predictability", the first of which is seen to cover two other notions: "possibility" and "certainty". The difference between "probability" on the one hand and "possibility" and "certainty" on the other is that while the first is described as "uncommitted", the second two are "committed" (Halliday 1970: 347).

Moreover, since modality is referred to as "a form of participation by the speaker in the speech event", and since it is through modality that "the speaker associates with the thesis an indication of its status and validity in his own judgment", thus "intruding" and taking up a position (Halliday 1970: 335), modality - is placed as part of the interpersonal function. This is the case since it expresses "a role relationship between the speaker and hearer" in the sense that "the speaker is taking upon himself a particular communicative role" through which he determines both his own role as well as the hearer's in relation to each other (Halliday 1970: 325).

Modality represents those choices in language which lie between the two polarities ("yes" and "no"), thus covering all intermediate degrees as well as the "various kinds of indeterminacy" that fall in between these two extreme, categorical choices (Halliday 1985: 85-86). It can be classified into modalization and modulation, depending on the two types of communicative activities to which it relates the two 
areas of meaning which it covers. The first area of meaning deals with propositions and is tackled under modalization. This branch of modality is seen to reflect the speaker's judgement of the likelihood of the proposition, and is, according to Halliday further subdivided into two sections depending on the two kinds of intermediate possibilities: degrees of probability and degrees of usuality (Halliday 1985: 86). The second area of meaning deals with proposals and is covered under modulation, the second main subsection of modality. This branch of modality, Halliday (1985: 86) explains, essentially reflects the speaker's desirability of the proposition and is also divided into two kinds of proposals: obligation and inclination.

Halliday (1985: 336) also categorizes modality into four different orientations in modality. They could be either subjective-explicit (I think Mary knows) or subjective-implicit (Mary'll know) on the one hand, or they could be either objectiveexplicit (it's likely that Mary knows) or objective-implicit (Mary probably knows) on the other. And finally, the third variable is what Halliday refers to as the different values attributed to modal forms and these can be low, median or high (Halliday 1985: 337). In that light, modalization would include various intermediary degrees of probability (possible/ probable/ certain) and usuality (sometimes/ usually/ always), while modulation would cover different degrees of obligation (allowed, supposed, required) and inclination (willing, keen, determined) (Halliday 1985: 335). These correspond respectively to the low, median and high values.

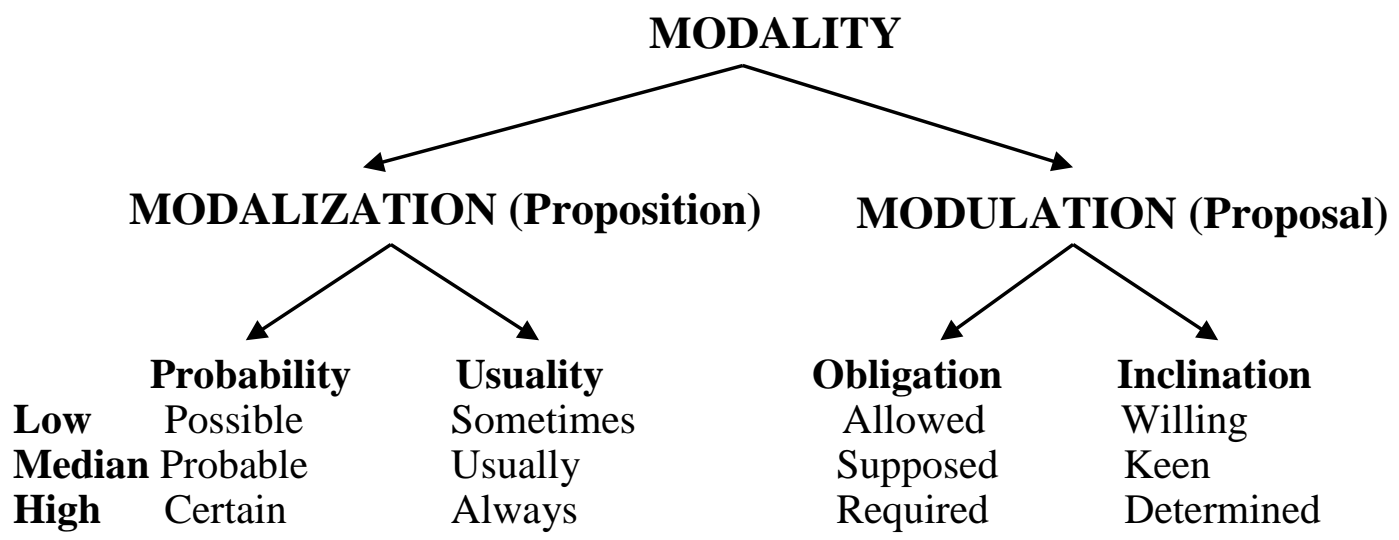

Figure 2.1 Kinds of Modality They are;

Halliday (1985) also classifies modal auxiliaries in three values of modality.

High : must, ought to, need, has to, is to

Median : will, would, shall, should

Low : may, might, can, could

But they can occur in all four types of modality (possibility, usuality, obligation and inclination). Different from Halliday, Dixon (2005) classifies modal and semi-modal in certain central meaning. It is shown as the table below; 


\begin{tabular}{|c|c|c|}
\hline Modal & Semi-modal & Central meaning \\
\hline Will/Would & \multirow{2}{*}{ Se going to } & \multirow[b]{2}{*}{ Prediction } \\
\hline Shall & & \\
\hline Should & \multirow{2}{*}{-} & \multirow[b]{2}{*}{ Obligation } \\
\hline Ough to & & \\
\hline \multirow[b]{2}{*}{ Must } & Have to & \multirow[b]{2}{*}{ Necessity } \\
\hline & Have got to & \\
\hline Can/Could & Be able to & Ability \\
\hline - & $\mathrm{Be}$ about to & Immenent activity \\
\hline Be to & - & Scheduled acituvity \\
\hline May/Might & - & Possibility \\
\hline - & Get to & Achievement \\
\hline- & Be bound to & Inevitability \\
\hline
\end{tabular}

Table 2.1 Classification of modals and semi-modals based on Dixon

B. Discourse Analysis

Discourse, in Latin: discursus, means "running to and from" (Oxford English Dictionary, 1961). Term of discourse is defined as communications in written and spoken ways. It has many definitions based on the approaches that used to discuss this term. On other ways, discourse contains different meanings in different studies. Stef Slembrouck in Purbani (2009) categorizes that there are at least 8 approaches used in developing theory and method of discourse analysis. The approaches as Slembrouck meant are philosophy, linguistic, anthropolinguistic, cultural studies, postructuralist, social theory and sociology. Then, if each approach contributed more than two theories or method, it could be imagined how complex the definition of discourse and discourse analysis are.

Fairclough (1989) views discourse as language use that is socially determined. Somebody will use language to communicate with others in order to hold a social activity. It can be said that language is a part of society and also a social process. Fairclough (1989) simplifies 'discourse as a social practice'. It is about language and practice; language is what is said and practice is custom or something done and acted. Margareth (2001) also corroborated that there is indexical relationship between utterances and something happens in social situation, but the concept of discourse is about where meaning comes from, not about whether things exist.

Discourse as a social practice of language always involves the context. According to anthropologist Malinowski (in Wetherell, 2001:82), a context of situation drives in language use; by considering a context of situation, an utterance can be understood. Context does not only consist of situation such as place and time setting, but Malinowski insisted that context had to be viewed in a wider sociological and cultural framework'. Fairclough (1898) also elaborates how context and language use are connected to be a discourse. Context involves the social conditions of production that is influenced by member resource and identity of speaker, the social condition of interpretation that is influenced by member resource and identity of 
listener. It means that discourse not only relate to how language is produced by the speaker, but also relates to how language is interpret by the listener.

It seems that discourse analysis is a study of language that more accurate rather than only the study of sentence or clause. Moreover, McCharthy (1991) defines discourse analysis as the study of the relationship between language and the context which it is used as some explanation above. It means that discourse analysis can cover the study of the spoken and written form as long as the context is counted. It will be complicated, because discourse never consists of one statement, one text, one action or one source only. Moreover, discourse analysis concerns with the production of knowledge and meaning, not only through language.

\section{RESEARCH METHODOLOGY}

1. Research Design

This research is a comparative study between political debates in Indonesia and USA. To compare those political debates, the researcher used descriptive qualitative method. The aim of descriptive qualitative research is to obtain an accurate profile of the people, events or situations, so it guides the researcher to explore the comparison in comprehensive, extensive and deep ways (Sugiyono, 2013).

\section{Source of Data}

There are two data of this research. The first is political debate "Indonesia Bersuara" showed in Metro TV. It can be found some episodes, but the researcher only chose 'Beda Mega Beda SBY'. The second data is the political debate in USA which was named as Obama vs. Romney. It can be downloaded from youtube.com. In choosing those videos of political debate, the researcher used purposive sampling by considering the position between two parties as the speakers; they should be equal.

\section{Social Situation}

Based on Sugiyono (2013), there are three aspects of social situation namely place, actors and activities. Related to this research, the social situations are;

\begin{tabular}{|l|l|l|}
\hline Social Situation & \multicolumn{1}{|c|}{ Beda Mega Beda SBY } & Obama vs. Romney \\
\hline Place & $\begin{array}{l}\text { Studio of Metro TV in Kebon } \\
\text { Jeruk Jakarta }\end{array}$ & $\begin{array}{l}\text { Hofstra University in } \\
\text { New York }\end{array}$ \\
\hline
\end{tabular}




\begin{tabular}{|l|l|l|}
\hline Actors & $\begin{array}{l}\text { 1. Fessi Alwi (Presenter) } \\
\text { 2. Marbawi (Jury) }\end{array}$ & $\begin{array}{l}\text { 1. Candy Crowley } \\
\text { (Presenter) }\end{array}$ \\
3. Iksan Mojo (Demokrat) & $\begin{array}{l}\text { 2. Obama } \\
\text { (Democratic) }\end{array}$ \\
4. Ahmad Qosasi (Demokrat) & $\begin{array}{l}\text { 5. Romney } \\
\text { (Republican) }\end{array}$ \\
& $\begin{array}{l}\text { 6. Evadhan Pohan } \\
\text { 7. Haso Kristiyanto (PDIP) } \\
\text { 8. Arya Bima (PDIP) }\end{array}$ & $\begin{array}{l}\text { Both political debates, generally, had same activities. } \\
\text { Politician as the speakers of debate did constructive and } \\
\text { rebuttal speech. Through the given issue, they tried to } \\
\text { convince audience by presenting their arguments. After } \\
\text { they debated, there was polling to choose the side that they } \\
\text { assumed be the best. }\end{array}$ \\
\hline
\end{tabular}

Table 3.1 Social situation of both political debates

4. Techniques of Analysing Data

The researcher used some techniques of analysing data in order to answer the research questions in the first chapter. They are;

1. First, the researcher transcribed the utterance of the speakers. To make a detail transcript, the researcher used the Adobe Premier S6. This application can be used to cut the video of political debate into each sentence of speaker.

2. Second, next sentence that has been transcribed is the source of data.

3. Third, the researcher the classified modalities used. It was categorized based on the classification of modality from Halliday (1985), and it was showed in table.

a. The indicator of deciding whether explicit or implicit is the using of pronoun ' $\mathrm{I}$ ' or 'We' as the subject of utterances which have sense of modality. It is categorized as subjective explicit, if the speakers use 'I' or "We' as the subject. Meanwhile, it is categorized as subjective implicit, if the speakers do not use 'I' or 'We' as the subject; they use other words which do not index the speakers' selves.

b. The next classification of modality is based on its type. As Halliday has explained, there are four types of modality; probability, usuality, obligation and inclination.

4. Next, make a recapitulation table which shows the differences and the similarities between Indonesian and American in using modality when they are involved in political debate.

5. Lastly, the researcher built conclusion. 


\section{FINDINGS}

1. Modalities used in Political Debate Discourse

Here are the modalities used by the speakers of Presidential Debate 'Obama vs. Romney' and 'Beda Mega Beda SBY'. Commonly, the findings are showed in some tables based on the classification from Halliday, and each table shows the modalities used by one speaker.

a. Modalities in Presidential Debate Obama vs Romney

The next tables present modalities used by the speakers of presidential debate 'Obama vs. Romney'. The speakers are the presenter, Romney and Obama. First, the presenter used some modalities in her utterances, and they are show in table as follows;

\begin{tabular}{|c|c|c|c|c|}
\hline \multirow[t]{2}{*}{ Modality } & \multicolumn{2}{|c|}{ Subjective } & \multicolumn{2}{|c|}{ Objective } \\
\hline & Explicit & Implicit & Implicit & Explicit \\
\hline \multicolumn{5}{|c|}{ Probability } \\
\hline Low & & & $\begin{array}{l}\square \text { What can } \\
\text { you do? }\end{array}$ & \\
\hline Median & & $\begin{array}{l}\square . ., \text { and there } \\
\text { will be a two } \\
\text { minute follow } \\
\text { up. }\end{array}$ & & \\
\hline High & $\begin{array}{l}\text { - My goal is to } \\
\text { give the } \\
\text { conversation } \\
\text { direction and } \\
\text { to ensure } \\
\text { questions get } \\
\text { answered. } \\
\text { - I'm sure the } \\
\text { candidates will } \\
\text { oblige by } \\
\text { keeping. }\end{array}$ & $\begin{array}{l}\text { Their } \\
\text { questions } \\
\text { will drive } \\
\text { the night. }\end{array}$ & & $\begin{array}{l}\text {.., so, the } \\
\text { first } \\
\text { question } \\
\text { will go to } \\
\text { you. } \\
\text { - The next } \\
\text { question is } \\
\text { going to be } \\
\text { for you } \\
\text { here. }\end{array}$ \\
\hline \multicolumn{5}{|l|}{ Obligation } \\
\hline Low & $\begin{array}{l}\text { - I want to move } \\
\text { you on to } \\
\text { something ... } \\
\text { - We want to get } \\
\text { a question } \\
\text { from Philip } \\
\text { Tricola. }\end{array}$ & $\begin{array}{l}\text { We will set } \\
\text { aside that } \\
\text { agreement } \\
\text { just this once } \\
\text { to welcome } \\
\text { President } \\
\text { Barack } \\
\text { Obama and } \\
\text { Governor } \\
\text { Mitt }\end{array}$ & & \\
\hline
\end{tabular}




\begin{tabular}{|c|l|l|l|l|}
\hline & & Romney. & & \\
\hline High & $\begin{array}{l}\square \text { I will let you } \\
\text { absolutely... }\end{array}$ & & $\begin{array}{c}\square \text { Let me give } \\
\text { the president } \\
\text { a chance. }\end{array}$ \\
\hline Inclination & $\begin{array}{l}\text {-... I want to get } \\
\text { right to it } \\
\text { - And I want to a } \\
\text { first-time } \\
\text { voter... }\end{array}$ & & \\
\hline
\end{tabular}

Table 4.1 Modalities used by the presenter

Romney also used some modalities in his speech to help him persuading other. Here is the table that presents modalities used by Romney;

\begin{tabular}{|c|c|c|c|c|}
\hline \multirow[t]{2}{*}{ Modality } & \multicolumn{2}{|l|}{ Subjective } & \multicolumn{2}{|c|}{ Objective } \\
\hline & Explicit & Implicit & Implicit & Explicit \\
\hline \multicolumn{5}{|c|}{ Probability } \\
\hline Low & & $\begin{array}{l}\square \text { They could } \\
\text { start hiring } \\
\text { more } \\
\text { people. }\end{array}$ & & \\
\hline Median & $\begin{array}{l}\square \text { I want you to } \\
\text { be able to get a } \\
\text { job. }\end{array}$ & & & \\
\hline High & $\begin{array}{l}\text { - We're also } \\
\text { going to have } \\
\text { our loan } \\
\text { program, so } \\
\text { that people are } \\
\text { able to afford } \\
\text { school. } \\
\text { - I'm going to } \\
\text { change that. } \\
\text { - I'm going to } \\
\text { do that. } \\
\text {-.., I presume } \\
\text { I'm going to be } \\
\text { president. } \\
\text { - I'm going to } \\
\text { make sure you } \\
\text { get a job. } \\
\text { - I want to make } \\
\text { sure that we }\end{array}$ & $\begin{array}{l}\text { - And kids } \\
\text { across this } \\
\text { country are } \\
\text { going to } \\
\text { recognize,.. } \\
\text { - It is not } \\
\text { going to be } \\
\text { like last } \\
\text { four years. }\end{array}$ & & $\begin{array}{l}\text { - It's going to } \\
\text { help Jeremy } \\
\text { get a job when } \\
\text { he comes out } \\
\text { of school. } \\
\text { - It's going to } \\
\text { help people } \\
\text { across the } \\
\text { countries that } \\
\text { are } \\
\text { unemployed } \\
\text { right now. } \\
\text { - But the key } \\
\text { thing is to } \\
\text { make sure you } \\
\text { can get a job } \\
\text { when you get } \\
\text { out of school. }\end{array}$ \\
\hline
\end{tabular}




\begin{tabular}{|c|c|c|c|c|}
\hline & $\begin{array}{l}\text { understand... } \\
\text { - I want to make } \\
\text { sure we keep } \\
\text { our Pell grant } \\
\text { program } \\
\text { growing. } \\
\text { - We have to } \\
\text { make sure that } \\
\text { we make it } \\
\text { easier for kids } \\
\text { to afford } \\
\text { college. }\end{array}$ & & & \\
\hline \multicolumn{5}{|c|}{ Obligation } \\
\hline High & & $\begin{array}{l}\square \text { So what we } \\
\text { have to do is } \\
\text { two things. }\end{array}$ & $\begin{array}{l}\square \text {..., you had o } \\
\text { t pass } \\
\text { exam. }\end{array}$ & \\
\hline \multicolumn{5}{|c|}{ Inclination } \\
\hline High & $\begin{array}{l}\text { And I think it's } \\
\text { important to } \\
\text { know... }\end{array}$ & & $\bar{\square}$ & $\begin{array}{l}\text { That was } \\
\text { precisely what I } \\
\text { recommended. }\end{array}$ \\
\hline
\end{tabular}

Table 4.2Modalities used by Romney

The next table presents modalities that used by Obama in his speech. Mostly, he showed himself as the subject implicitly.

\begin{tabular}{|c|c|c|c|c|}
\hline \multirow[t]{2}{*}{ Modality } & \multicolumn{2}{|c|}{ Subjective } & \multicolumn{2}{|c|}{ Objective } \\
\hline & Explicit & Implicit & Implicit & Explicit \\
\hline \multicolumn{5}{|c|}{ Probability } \\
\hline Low & & $\begin{array}{l}\text { - Ones can support a } \\
\text { family. } \\
\text { - .., take the executives } \\
\text { at GM and Chrysler, } \\
\text { some of whom are } \\
\text { Republicans, may } \\
\text { even support } \\
\text { Governor Romney. } \\
\text { - You can make a lot of } \\
\text { money.. } \\
\text { - You can ship jobs } \\
\text { overseas and get tax } \\
\text { for it. } \\
\text { - You can invest in a } \\
\text { company }\end{array}$ & & \\
\hline Median & & $\begin{array}{l}\square \text { We would have lost a } \\
\text { million jobs. }\end{array}$ & & \\
\hline
\end{tabular}




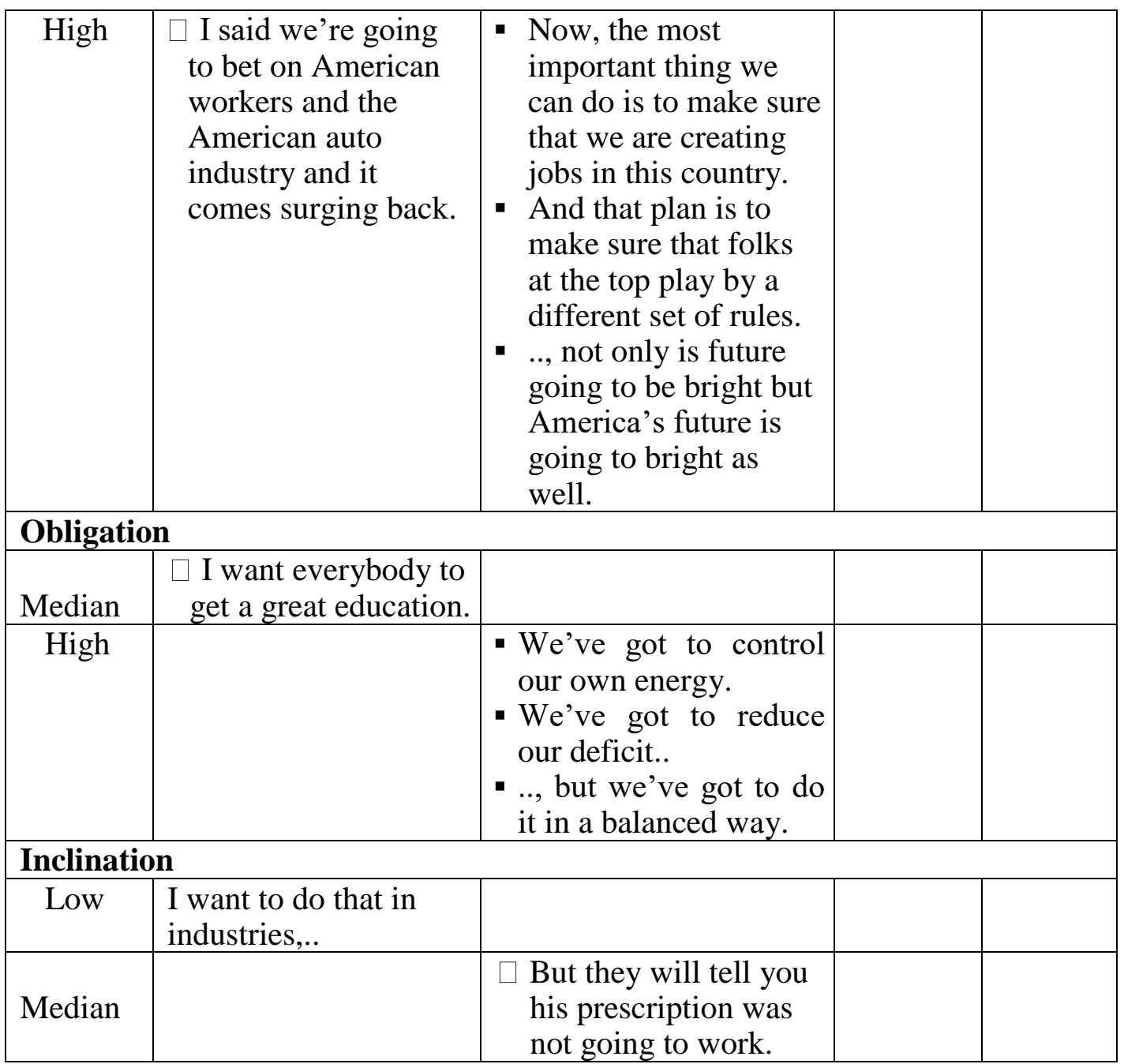

Table 4.3 Modalities used by Obama

b. Modalities in Beda Mega Beda SBY

From 'Beda Mega Beda SBY', it can be seen that there are four tables. The first is table of modalities used by the presenter of 'Beda Mega Beda SBY'.

\begin{tabular}{|l|l|l|c|c|}
\hline \multirow{2}{*}{ Modality } & \multicolumn{2}{|c|}{ Subjective } & \multicolumn{2}{c|}{ Objective } \\
\cline { 2 - 5 } & \multicolumn{1}{|c|}{ Implicit } & Implicit & Explicit \\
\hline Probability & - Kita akan & & \\
\hline Median & menampilkan & & \\
& & & \\
& tiga isu. & & \\
& - Nanti kita akan & & \\
& kembali dengan & & \\
& menganalisa & & \\
\end{tabular}




\begin{tabular}{|c|c|c|}
\hline & $\begin{array}{l}\text { bagaimana } \\
\text { kebijakan politik } \\
\text { dan ketahanan } \\
\text { pangan. } \\
\text { - Kita akan kembali } \\
\text { untuk mengupas } \\
\text { soal bagaimana } \\
\text { komitmen mereka } \\
\text { terhadap } \\
\text { pemberantasan } \\
\text { korupsi..., } \\
\text { - keenam politisi } \\
\text { pada malam hari } \\
\text { ini yang akan } \\
\text { membela partai } \\
\text { politik dan } \\
\text { tokohnya masing- } \\
\text { masing. } \\
\end{array}$ & \\
\hline High & & $\begin{array}{l}\text { Ini diduga kuat } \\
\text { disebabkan oleh } \\
\text { beberapa hasil } \\
\text { survey yang } \\
\text { membuat SBY } \\
\text { lebih unggul } \\
\text { dari Megawati } \\
\text { jika pilpres } \\
\text { digelar. } \\
\end{array}$ \\
\hline \multicolumn{3}{|c|}{ Usuality } \\
\hline Low & $\begin{array}{l}\square \text { Mega sudah tiga } \\
\text { kali } \\
\text { menaikkan harga } \\
\text { BBM, dan belum } \\
\text { pernah sekalipun } \\
\text { menurunkan } \\
\text { harga BBM. }\end{array}$ & $\begin{array}{l}\text { Termasuk juga } \\
\text { partai politik } \\
\text { mereka yang } \\
\text { bisa dikatakan } \\
\text { tidak pernah } \\
\text { satu pendapat } \\
\text { dalam } \\
\text { mengatasi } \\
\text { persoalan } \\
\text { bangsa ini. } \\
\end{array}$ \\
\hline Median & $\begin{array}{l}\text { Kedua tokoh ini } \\
\text { kerap kali } \\
\text { bersebrangan. }\end{array}$ & \\
\hline
\end{tabular}




\begin{tabular}{|c|c|c|c|}
\hline High & & & $\begin{array}{l}\text { Kebijakannya } \\
\text { masing-masing } \\
\text { bisa dikatakan } \\
\text { cukup bertolak } \\
\text { belakang kerap } \\
\text { kali. }\end{array}$ \\
\hline \multicolumn{4}{|c|}{ Obligation } \\
\hline Median & $\begin{array}{l}\text { Saya ingin } \\
\text { dengarkan } \\
\text { yelyel } \\
\text { terlebih } \\
\text { dahulu } \\
\end{array}$ & & \\
\hline \multicolumn{4}{|c|}{ Inclination } \\
\hline Low & \begin{tabular}{l}
\multicolumn{1}{c}{ Saya akan } \\
memperkenal \\
ka n keeam \\
politisi pada \\
malam hari ini \\
..
\end{tabular} & & \\
\hline Median & & $\begin{array}{l}\text { Dan yang } \\
\text { ketiga adalah } \\
\text { juri yang akan } \\
\text { menganalisa } \\
\text { jalannya debat } \\
\text { malam hari ini. }\end{array}$ & \\
\hline High & & $\begin{array}{l}\text { Suara } \\
\text { mahasiswa } \\
\text { melalui poling } \\
\text { akan } \\
\text { menentukan } \\
\text { mana partai yang } \\
\text { bisa atau lebih } \\
\text { mereka percaya. }\end{array}$ & \\
\hline
\end{tabular}

Table 4.4 Modalities used by the Presenter Beda Mega Beda SBY

The second table presents the modalities used by the jury of 'Beda Mega Beda SBY. There are only three examples of modality, because he is only given little chance to speak.

\begin{tabular}{|l|c|c|c|c|}
\hline \multirow{2}{*}{ Modality } & \multicolumn{2}{|c|}{ Subjective } & \multicolumn{2}{c|}{ Objective } \\
\cline { 2 - 4 } & Explicit & Implicit & Implicit & Explicit \\
\hline Probability & \multicolumn{3}{|l}{} \\
\hline
\end{tabular}




\begin{tabular}{|c|c|c|c|}
\hline Low & \multicolumn{2}{|l|}{$\begin{array}{l}\square \text { Mungkin yang } \\
\text { Mas Arya Bima } \\
\text { tadi sebagai } \\
\text { penciteraan. }\end{array}$} \\
\hline Inclination & & & \\
\hline Median & $\begin{array}{l}\square \text { Saya kira banyak dari } \\
\text { kalangan partai } \\
\text { demokrat,komunikasi } \\
\text { politik itu sesuatu yang } \\
\text { harus diolah. }\end{array}$ & & \\
\hline
\end{tabular}

Table 4.5Modalities used by the jury

The third table presents some modalities that have been used by the Eva Sundari, Haso Kristiyanto and Arya Bima as the representative of PDIP party.

\begin{tabular}{|c|c|c|c|c|}
\hline \multirow[b]{2}{*}{ Modality } & \multicolumn{2}{|c|}{ Subjective } & \multicolumn{2}{|c|}{ Objective } \\
\hline & Explicit & Implicit & Implicit & Explicit \\
\hline \multicolumn{5}{|c|}{ Probability } \\
\hline Low & & $\begin{array}{l}\text { - ... Indonesia } \\
\text { bisa bangkit } \\
\text { kembali. } \\
\text { - Indonesia bisa } \\
\text { berdiri di atas } \\
\text { kaki sendiri... }\end{array}$ & & \\
\hline Median & & $\begin{array}{l}\square \quad \text { Pak SBY } \\
\text { menjadi akan } \\
10 \text { tahun }\end{array}$ & & \\
\hline High & $\begin{array}{l}\text { Saya kira } \\
\text { dia keliru, } \\
\text { jadi } \\
\text { maafkan } \\
\text { saja }\end{array}$ & $\begin{array}{l}\square \quad \text {..ia harus } \\
\text { memberi contoh } \\
\text { yang baik, } \\
\text { lebihlebih bagi } \\
\text { partai yang } \\
\text { sudah } \\
\text { mengiklankan } \\
\text { dirinya untuk } \\
\text { memberantas } \\
\text { korupsi. }\end{array}$ & & \\
\hline
\end{tabular}




\begin{tabular}{|c|c|c|c|}
\hline Low & & $\begin{array}{l}\text { - Belum pernah } \\
\text { SBY mengatakan } \\
\text { konsep } \\
\text { kedaulatan } \\
\text { pangan nasional. } \\
\text { - Dan Bulog tidak } \\
\text { pernah punya } \\
\text { stok lebih dari } \\
800 \text { ribu ton dari } \\
2 \text { juta kebutuhan. }\end{array}$ & \\
\hline \multicolumn{4}{|c|}{ Obligation } \\
\hline High & & $\begin{array}{l}\text { - Dan itu adalah } \\
\text { penyakit yang } \\
\text { harus kita berntas } \\
\text { bersama } \\
\text { - Dimana Negara } \\
\text { harus } \\
\text { hadir } \\
\text { membantu rakyat } \\
\text { yang tertindas... }\end{array}$ & $\begin{array}{l}\text { - Harus dilihat } \\
\text { bahwa } \\
\text { pebandingan } \\
\text { tidak bisa } \\
\text { apple to apple } \\
\text { - Inilah yang } \\
\text { harus dipikirkan } \\
\text { bersama-sama. } \\
\text { - Ini harus } \\
\text { dijawab teman- } \\
\text { teman } \\
\text { demokrat. }\end{array}$ \\
\hline \multicolumn{4}{|c|}{ Inclination } \\
\hline Low & $\begin{array}{l}\text { Saya hanya } \\
\text { ingin } \\
\text { mengingatkan } \\
\text { ada menkes.. } \\
\square \text { Kemudian } \\
\text { yang ingin } \\
\text { saya } \\
\text { katakan,.. } \\
\end{array}$ & & .. \\
\hline High & & $\begin{array}{l}\text { Sebagai Negara } \\
\text { yang berdaulat, } \\
\text { maka yang berhak } \\
\text { menilai adalah } \\
\text { rakyat. }\end{array}$ & $\begin{array}{l}\text { Dan harus } \\
\text { dicatat, } \\
\text { impor } \\
\text { pangan } \\
\text { sama saja } \\
\text { mensejahterakan } \\
\text { petani luar, } \\
\text { bukan petani } \\
\text { Indonesia. } \\
\end{array}$ \\
\hline
\end{tabular}

Table 4.6 Modalities used by the speakers of PDI Perjuangan 
The fourth table presents the modalities that used by the speakers of Demokrat party; they are Iksan Mojo, Ahmad Qosasi and Ramadhan Pohan. The modalities in this table are collected from those politicians.

\begin{tabular}{|c|c|c|c|c|}
\hline \multirow[t]{2}{*}{ Modality } & \multicolumn{2}{|c|}{ Subjective } & \multicolumn{2}{|c|}{ Objective } \\
\hline & Explicit & Implicit & Implicit & Explicit \\
\hline \multicolumn{5}{|c|}{ Probability } \\
\hline Low & $\begin{array}{l}\text { - Kita tidak } \\
\text { akan } \\
\text { menghina } \\
\text { orang lain. } \\
\text { - kita tidak } \\
\text { akan } \\
\text { menghina } \\
\text { partai lain. } \\
\text { - kita tidak } \\
\text { akan } \\
\text { mengejek } \\
\text { partai lain. }\end{array}$ & & & \\
\hline Median & & $\begin{array}{l}\text { - Seorang peragu| } \\
\text { tidak akan } \\
\text { mungkin } \\
\text { menempatkan } \\
\text { dirinya| untuk } \\
\text { mempertahanka } \\
\text { n daerahnya e } \\
\text { satu centipun. } \\
\text { - Dan insya Allah } \\
\text { 2009-2014| } \\
\text { khusnul } \\
\text { khatimah|| SBY } \\
\text { bisa } \\
\text { mengamankan } \\
\text { pemerintahannya }\end{array}$ & & \\
\hline High & & $\begin{array}{l}\text { Itu tidak bisa } \\
\text { kita bantah, } \\
\text { lembaga } \\
\text { internasioanl } \\
\text { mau mengatakan } \\
\text { SBY, he is a } \\
\text { great } \\
\text { communicator. }\end{array}$ & & \\
\hline
\end{tabular}




\begin{tabular}{|c|c|c|c|c|}
\hline High & & & & $\begin{array}{l}\text { Y Yang pada saat } \\
\text { beliau masih } \\
\text { tentara aktif } \\
\text { namanya turun } \\
\text { ke bawah itul } \\
\text { sudah sering } \\
\text { dilakukan oleh } \\
\text { beliau. }\end{array}$ \\
\hline \multicolumn{5}{|c|}{ Obligation } \\
\hline High & & $\begin{array}{l}\text { Kita harus } \\
\text { menyadari } \\
\text { bahwa dalam } \\
\text { soal } \\
\text { pemberantasan } \\
\text { korupsi, } \\
\text { presiden SBY } \\
\text { adalah yang } \\
\text { terbaik di dunia. } \\
\square \quad \text { Pemimpin } \\
\text { harus turun ke } \\
\text { bawah } \\
\text { berdialog } \\
\text { langsung.. }\end{array}$ & $\begin{array}{l}\text { Apa yang } \\
\text { dilakukan } \\
\text { SBY, apa } \\
\text { yang } \\
\text { dilakukan } \\
\text { Jokowi } \\
\text { semestinya } \\
\text { tidak perlu } \\
\text { diperdebatkan } \\
\text {. Tapi harus } \\
\text { diingat juga.. } \\
\text { - Dan harus } \\
\text { diketahui } \\
\text { juga... } \\
\text { - Jangan lupa } \\
\text { juga.. } \\
\end{array}$ & $\begin{array}{l}\text { - Dalam hal } \\
\text { ini,yang } \\
\text { harus } \\
\text { diperhatikan, } \\
\text { memang ada } \\
\text { kondisi fiscal.. } \\
\text { - Jadi konteks } \\
\text { pemberian } \\
\text { blok Cepu ini } \\
\text { harus dilihat } \\
\text { juga } \\
\text { dalamsystem } \\
\text { skema bagi } \\
\text { hasilnya. } \\
\end{array}$ \\
\hline \multicolumn{5}{|c|}{ Inclination } \\
\hline \multirow[t]{2}{*}{ Low } & $\begin{array}{l}\text { Satu hal } \\
\text { yang ingin } \\
\text { saya } \\
\text { sampaikan. }\end{array}$ & & & \\
\hline & $\begin{array}{l}\text { Saya hanya } \\
\text { ingin } \\
\text { mengatakan.. }\end{array}$ & & & \\
\hline
\end{tabular}

Table 4.7 Modalities used by the speakers of Demokrat

2. The Similarity and the Difference of Political Debate in America and Indonesia

The last explanations are about the similarities and differences between American and Indonesian in using modality when they are involved in political debate. The first similarity, politicians from both countries used high value of modality such as certainty, always, required and determined. Those kinds of modality showed that the politicians from both countries had high commitment toward the proposition and the topic that they were talking about. For instance, 


\begin{tabular}{|l|l|}
\hline \multicolumn{1}{|c|}{ Indonesian } & \multicolumn{1}{c|}{ American } \\
\hline 'We have to realize that, SBY is \\
the best in the history of \\
Indonesia.'
\end{tabular}

Table 4.8 High modality used by politicians

The second similarity is both presenters from those political debates tended to use median value of modality. They actually wanted to state some regulations that required or have to be followed, but the presenters chose to use median value of modality. It showed their attitude toward the politicians and their commitments are in median level. For instance;

\begin{tabular}{|c|c|}
\hline \multicolumn{1}{|c|}{ Indonesian } & \multicolumn{1}{c|}{ American } \\
\hline $\begin{array}{l}\text { 'I would like to listen to the cheers } \\
\text { first.' }\end{array}$ & $\begin{array}{l}\text { '.., and there will be a two minute } \\
\text { follow up.' }\end{array}$ \\
\hline
\end{tabular}

Table 4.9 Modalities used by both presenters

The different thing is the American are more explicit to put their selves as the subject of assessment rather than the Indonesian speakers of political debate. For instance,

\begin{tabular}{|l|l|}
\hline \multicolumn{1}{|c|}{ Indonesian } & \multicolumn{1}{c|}{ American } \\
\hline '(I think) It cannot be denied.' & I think it's important to know.' \\
\hline $\begin{array}{l}\text { 'Next, (I want) the jury will analyses } \\
\text { the debate tonight' }\end{array}$ & $\begin{array}{l}\text { 'I want to move you on to } \\
\text { something.' }\end{array}$ \\
\hline $\begin{array}{l}\text { 'By God willing, (I want to make sure } \\
\text { that }) \text { SBY is able to end his governance } \\
\text { blissfully' }\end{array}$ & 'I want to make sure, you get a job.' \\
\hline
\end{tabular}

Table 4.10 The differences between American and Indonesian in using modality

\section{DISCUSSION}

The result of this research shows that the speakers of both political debates used modality in three values such as high, median and low value. Commonly, the result of this research confirms the concept of politeness that it has to be interpreted functionally. The meaning of modality does not only deals with its structure but also the context of using. In more specific analysis, the researcher found something different from the category of modality from Halliday. Modal auxiliaries are categorized as;

High : must, ought to, need, has to, is to

Median : will, would, shall, should

Low : may, might, can, could (Halliday, 1985:339) 
As an instance, 'will' is categorized as modal which expresses median value of modality. In fact, it is mostly used to express high values or something which has high possibility to happen. One of data which used 'will' to express high value of modality is 'their questions will drive the night'; the speakers said this sentence after preparing a number of voter to ask each questions. Because the voter had been already in the studio and they have already had a question, it indicates that the possibility of driving that political debate by the voters' question is high.

Additionally, the modal auxiliary such as can could, may, might, shall, should, will, would, must, ought to, is to, has to, etc cannot be used as the indicator to examine the types of modality in a sentences, because they can occur in all four types. In different explanation, they can be used as indicator in examining the values of modality especially for English data. But the problem is examining modals or semimodals in Indonesian data cannot be accurately used to decide its values. Moreover, some modals and semi-modals in English do not have equivalent meaning in Bahasa system. For example, the words will, would, shall, and be going to are expressed with one word only namely 'akan'. The researcher needed to pay more attention to some conditional in context related to the using of akan if it is translated into English. The modal auxiliary 'akan' is categorized as low value with 'will or would', if it is used in expressing the intension only with no effort to realize. Next, 'akan' is categorized as high value and translated with 'be going to', if the speakers have done some steps to realize that proposition.

It also makes the researcher confusing the explanation and classification of modality from Dixon (2005). For example, Dixon (2005) stated that 'will' is a modal that has prediction as its central meaning; meanwhile, the researcher finds that 'will' was used the presenter of presidential debate Obama vs. Romney and Beda Mega Beda SBY to express the inclination sense of modality. It seems that the meaning of language cannot be determined only from its structure; it is important to paying attention toward the context of using.

Related to the similarities and the differences, some findings show that modality is used by the speakers as the strategy in persuading or expressing their attitude. It covers how politicians tended to use high value of modality to show their high commitment toward opinion or argument, and also how presenter tended to use median value of modality in offering the other speakers rather than the high value of modality; although the presenter actually wanted to state a requirement that should be followed.

Lastly, American and Indonesian have different way to show their selves; Indonesian tended to show their selves implicitly, while American were more explicit. And then, those ways are also strategies.

\section{CONCLUSION}

There are two conclusions of this research. The first is the speaker of political debate from Indonesian and American used high, median and low value of modality, and they have similarities and difference. The similarities are the high value of modality used by politician in America and Indonesian as the strategy to persuade 
other by showing their high commitment toward the topic, the median or low modality are used the presenters as the strategy also to balance their relationship with other speakers. Next, the difference is American people are more explicit to show themselves as the subject in modality; meanwhile Indonesian people are more implicit.

\section{BIBLIOGRAPHY}

Bloor, Thomas \& Meriel. 1995. The Functional Analysis of English. Oxford University Press Inc. Oxford.

Butt, David., et al. 1995. Using Functional Grammar. Claredon Printing Pty. New South Wales.

Cook, Guy. 1990. Discourse. Oxford University Press. Oxford.

Coulthard, Malcolm. 1990. An Introduction to Discourse Analysis. Longman Inc. New York.

Dijk, Teun A. Van. 1998. Ideology a Multidisciplinary Approach. SAGE Publications. London.

Dixon, R.M.W. 2005. A Semantic Approach to English Grammar. Oxford University Press. Oxford.

Fairclough, Norman. 1989. Language and Power. Longman Inc. $\quad$ New York.

Halliday, M. A. K. 1970. 'Functional Diversity in Language as Seen from a Consideration of Modality and Mood in English', Foundations of Language 6: 322 - 361 .

Halliday, M.A.K. 1985. An Introduction to Functional Grammar. Edward Arnold. London.

McCarthy, Michael. 1991. Discourse Analysis for Language Teachers. Cambridge University Press. Cambridge.

Sugiyono. 2013. Metode Peneitian Kuantitatif Kualitatif dan $R \& D$. CV.ALFABETA. Bandung.

Wetherell, Margareth., et al. (2001). Discourse Theory and Practice. Sage Publications. London. 